\title{
EFFECT OF WOOD FRACTIONAL COMPOSITION ON GASIFICATION PROCESS
}

In many countries of the world, biomass is becoming increasingly important in various sectors, in particular: at thermal and electric stations for the production of heat and electrical energy in district heating systems in chemical and timber industry complexes. It is known that the potential of biomass is ten times higher than the possible needs of mankind for energy, is environmentally friendly and has the ability to recover. Today there is a trend of decentralization of energy, that is, the use of cogeneration plants for generating heat and electricity. Perspective cogeneration units are internal combustion engines operating on synthesis gas. Therefore gasification of wood for the purpose of synthesis gas production is the most promising and ecological way of biomass processing. The calorific value of the synthesis gas produced as a result of the gasification of wood fuels can vary depending on various factors. The main factors affecting the gasification process are as follows: the fractional composition of wood; the amount of air supplied to the gasification chamber; height of the active layer and a number of other factors depending on the fuel that is gasified, and the parameters of the gasifier. Any wood for further thermal processing should be crushed. Depending on the need, the wood is crushed to the technological wood chips of various fractions by chipping machines that are also called wood crushers, or shredders. The choice of chippers depends on the production need. Modern chipping machines allow fine-tuning the raw material by the size of the wood. Taking into account the shortage and the price of energy carriers, the use of comminuted wood waste as a fuel for gas-generating plants and solid-fuel boilers comes to the fore.

Keywords: calorific value of synthesis gas; gas-generator installation; wood gasification process; fractional composition of wood.

Introduction. Physical and mechanical properties of chopped wood, except bulk weight, are no different from the properties of wood. The main difference of any loose material on the whole lies in its particles discretisation (sawdust, shavings, speck of dust). In this connection, weshould consider the physical and mechanical properties of individual particles and properties of the whole mass of the loose material. The moisture in the wood affects the physical and mechanical properties of wood in any of its kind. Even at higher wood moisture content of 14-16\% water acts as a lubricant at a given mechanical impact, especially during comminution when the pieces or particles are relatively large. At very low moisture content of wood (less than $4.5 \%$ ), water forms thin films in wood thickness. In this state, the wood becomes brittle, breaks easily and is easily shredded (Basu, Prabir, 2010; Lyamyn \& Nemkyn, 1940). At various operations with loose waste, we have to count certain other technical processes such as gasification, burning, etc.

Method for calculation the particles size of wood. In the process of gasification or burning of wood, particles size plays an important role. For calculations convenience and simplification, loose materials particles form is supposed to be spherical. In fact loose particles of wood differ in form from the sphere. Therefore the concept of equivalent diameter is introduced, i.e. linear particle size, equivalent to the diameter of the respective sphere.

The equivalent diameter of particles is determined by sieve analysis (Lyamyn \& Nemkyn, 1940) as follows:

$$
d_{e}=\sum_{i=1}^{k} x_{i} d_{i} / \sum_{i=1}^{k} x_{i},
$$

where $d_{i}$ - average sieve holes diameter; $k$ - number of primary fractions in the layer on dispersion size; $x_{i}$ - mass share of the fraction.

The average diameter $d_{i}$ is defined by the formula

$$
d_{i}=\sqrt{\frac{d_{1}^{2} d_{2}^{2}}{d_{1}+d_{2}}},
$$

where $d_{1}$ and $d_{2}$ are determined in accordance with the size of holes of passable and impassable sieves.

If the particle sizes are determined experimentally and they are very different in form from the sphere, the equivalent diameter of the particles can be determined by the formula:

$$
d_{e}=\phi \cdot d_{\kappa}
$$

where $\phi$ - factor or form factor; $d_{k}$ - diameter sphere, the amount of which is equivalent to the volume of the particle.

If the volume of the particles is equal to $V_{p}$, then when $V_{K}=V_{p}$ diameter sphere is equal to

$$
d_{\kappa}=\sqrt{\frac{V_{p}}{0,524}} .
$$

For spherical particles $\phi=1$, round $\phi=0,75$, shapeless $\phi=0,66$, oblong $\phi=0,58$, lamellar $\phi=0,43$.

Taking into account the fractional composition and amount of wood needed in this technological process, we choose a "PM-5P" shredder. Shredder is equipped with a pneumoconveyor or belt conveyor for the removal of chips, grinding device, control device to resize chips (chips size is

Цитування за ДСтУ: Лис С. С., Мисак Й. С., Кравець Т. Ю. Вплив фракційного складу деревини на процес газифікації. Науковий вісник НЛтУ України. 2017. Вип. 27(4). С. 119-121.

Citation APA: Lys, S. S., Mysak, Yo. S., \& Kravets, T. Yu. (2017). Effect of Wood Fractional Composition on Gasification Process. Scientific Bulletin of UNFU, 27(4), 119-121. https://doi.org/10.15421/40270426 
adjustable - length from $10 \mathrm{~mm}$ to $40 \mathrm{~mm}$, width $7 \mathrm{~mm}$ to $20 \mathrm{~mm}$ thickness from $1.5 \mathrm{~mm}$ to $5 \mathrm{~mm}$ ).

The purpose of the study. The study is aimed at determining the influence of the particle size of chopped wood on the gasification process and on the lower heating value of the synthesis gas.

Results of the research. Analysis of the impact of input parameters, one of which is the fractional composition of wood, the calorific value of syngas will help us find optimal regime parameters for gasification and laboratory gas generator, which allows developing technology for the gasification process and the constructive scheme for the industrial gas generator installation.

For the experimental research and the development of wood gasification process into gaseous fuel, gasifier with a continuous layer has been designed (Mysak, Lys \& Martynyak-Andrushko, 2017).

The problem was to find dependence of lower syngas calorific value on particle size of the chopped wood supplied to the gasifier, the amount of air and the amount of fuel in the gasification chamber.

In order to establish the nature of the variable factors influence on net calorific value of synthesis gas, the threelevel plan $\left(\mathrm{B}_{3}\right)$ (Mysak, Lys \& Martynyak-Andrushko, 2017; Pylypchuk, Hryhoryev \& Shostak, 2007) was Used. Levels and intervals of factors change are shown in the Table 1.

Table 1. Levels and intervals of factors change

\begin{tabular}{|c|c|c|c|c|c|c|}
\hline \multirow[b]{2}{*}{ Factors } & \multicolumn{2}{|c|}{$\begin{array}{c}\text { Factor de- } \\
\text { signation }\end{array}$} & \multicolumn{3}{|c|}{\begin{tabular}{|c}
$\begin{array}{c}\text { Levels of factor } \\
\text { changing }\end{array}$ \\
\end{tabular}} & \multirow{2}{*}{$\begin{array}{l}\text { Interval of } \\
\text { factor } \\
\text { changing }\end{array}$} \\
\hline & $\begin{array}{c}\text { natu- } \\
\text { ral }\end{array}$ & $\begin{array}{l}\text { nor- } \\
\text { mali- } \\
\text { zed }\end{array}$ & $(-1)$ & (0) & $(+1)$ & \\
\hline $\begin{array}{l}\text { Size of the wood par- } \\
\text { ticles, mm }\end{array}$ & $l$ & $x_{1}$ & 10 & 30 & 50 & 20 \\
\hline Amount of air, $\mathrm{nm}^{3} / \mathrm{hr}$ & $G$ & $x_{2}$ & 40 & 65 & 90 & 25 \\
\hline $\begin{array}{l}\text { Amount of fuel in the } \\
\text { gasifier reactor, \% }\end{array}$ & $q$ & $x_{3}$ & 50 & 75 & 100 & 25 \\
\hline
\end{tabular}

It has been established that the highest calorific value of synthesis gas is reached during the gasification of wood with a particle size of $30 \mathrm{~mm}$ (Fig. 1), the amount of air $65 \mathrm{~nm}^{3} / \mathrm{hr}$, fed into the gasification chamber, and the amount of fuel $75 \%$ of the total volume of the reactor.

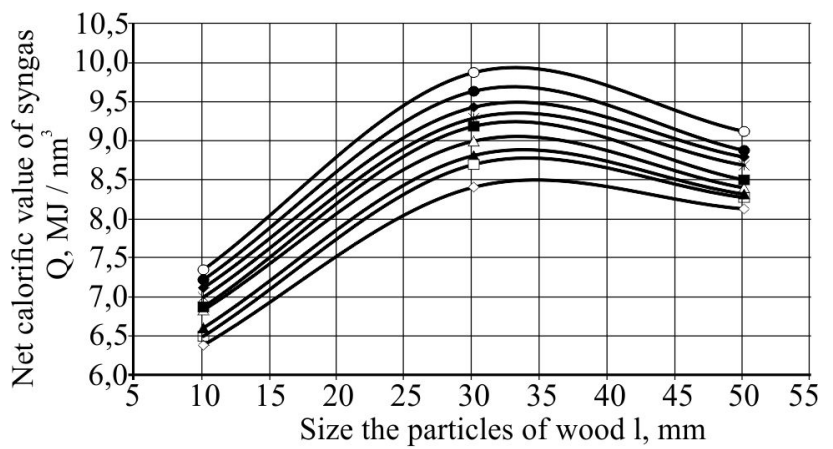

- amount of air $40 \mathrm{~m}^{3} / \mathrm{hr}$., amount of fuel $50 \%$ $\neg-$ amount of air $40 \mathrm{~m}^{3} / \mathrm{hr}$., amount of fuel $100 \%$ - amount of air $65 \mathrm{~m}^{3} / \mathrm{hr}$., amount of fuel $75 \%$ _ amount of air $90 \mathrm{~m}^{3} / \mathrm{hr}$., amount of fuel $50 \%$ $\rightarrow$ amount of air $90 \mathrm{~m}_{3}^{3} / \mathrm{hr}$., amount of fuel $100 \%$ - amount of air $40 \mathrm{~m}^{3} / \mathrm{hr}$., amount of fuel $75 \%$ \# amount of air $65 \mathrm{~m}^{3} / \mathrm{hr}$., amount of fuel $50 \%$ $\rightarrow$ amount of air $65 \mathrm{~m}^{3} / \mathrm{hr}$., amount of fuel $100 \%$ $\rightarrow$ amount of air $90 \mathrm{~m}^{3} / \mathrm{hr}$., amount of fuel $75 \%$

Fig. 1. Dependence of syngas net calorific value on particle size of chopped wood during pine wood gasification
During the wood gasification (pine) with decreasing particle size from $50 \mathrm{~mm}$ to $30 \mathrm{~mm}$, gas temperature at the outlet of the gasifier decreased. The rate of gasification process increased, which eventually led to a significant increase in productivity a gas generator and to a significant increase in the output of wood gasification of liquid products while increasing net calorific value of synthesis gas. Increased wood chopping leads to an increase in the surface, providing a significant heating rate of particles of wood and allocation of decomposition products on its surface. But with decreasee in the timber particle size from $30 \mathrm{~mm}$ to $10 \mathrm{~mm}$, we could observe decrease in net calorific value of synthesis gas because of the high density of fuel layer which in turn reduces the intensity of the gasification process.

As a result of experimental research (Pylypchuk, Hryhoryev \& Shostak, 2007; Lys \& Mysak, 2012) using B-plan $\left(\mathrm{B}_{3}\right)$ dependence of the net calorific value of synthesis gas $\left(Q_{H}^{p} \mathrm{MJ} / \mathrm{m}^{3}\right.$ ), for the process of wood gasification on such factors as: size of the wood particles $l=10,30,50 \mathrm{~mm}$; amount of air $G=40,65,90 \mathrm{~nm}^{3} / \mathrm{hr}$; amount of fuel in the gasifier reactor $q=50,75,100 \%$ has been established. Calculation of the regression coefficients $b_{i j}$, Cochran criterion $\mathrm{G}_{p}$ and Fisher criterion $\mathrm{F}_{p}$ (Mysak, Lys \& MartynyakAndrushko, 2017; Lys, 2017) for pine wood are provided in Table 2.

Table 2. The results of calculation of the regression coefficients, Cochran and Fisher criterions

\begin{tabular}{|c|c|c|c|c|c|c|c|c|c|c|c|c|c|}
\hline$b_{0}$ & $b_{1}$ & $b_{2}$ & $b_{3}$ & $b_{11}$ & $b_{22}$ & $b_{33}$ & $b_{12}$ & $b_{13}$ & $b_{23}$ & $G_{m}$ & $G_{p}$ & $F_{m}$ & $F_{p}$ \\
\hline$\stackrel{m}{N}$ & $\infty$ & \pm & $=$ & 고 & n & $\widetilde{N}$ & ㅇ. & $\overline{0}$ & 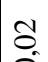 & $\stackrel{\infty}{+}$ & ஜூ & సิ & ñ \\
\hline & 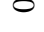 & 0 & 0 & 7 & ب & ب & 1 & ${ }_{1}$ & 0 & 0 & 0 & & \\
\hline
\end{tabular}

As a result of $B_{3}$-plan implementation, mathematical description of the object in a second order polynomial was obtained:

$$
\begin{gathered}
Q=-1,5562+0,2726 l+0.11256 G+0.06772 q-0.00375 l^{2}- \\
-0.000832 G^{2}-0.000432 \cdot q^{2}-0.00004 \cdot l \cdot G- \\
-0.00002 \cdot l \cdot q+0.000032 \cdot G \cdot q .
\end{gathered}
$$

Table 2 shows that $\mathrm{G}_{p} \leq \mathrm{G}_{m}(0,095 \leq 0,48)$, experiments can be considered reproducible. $F_{p} \leq F_{m}(0,2554 \leq 2,5027)-$ the model is considered adequate and can be used to describe the object.

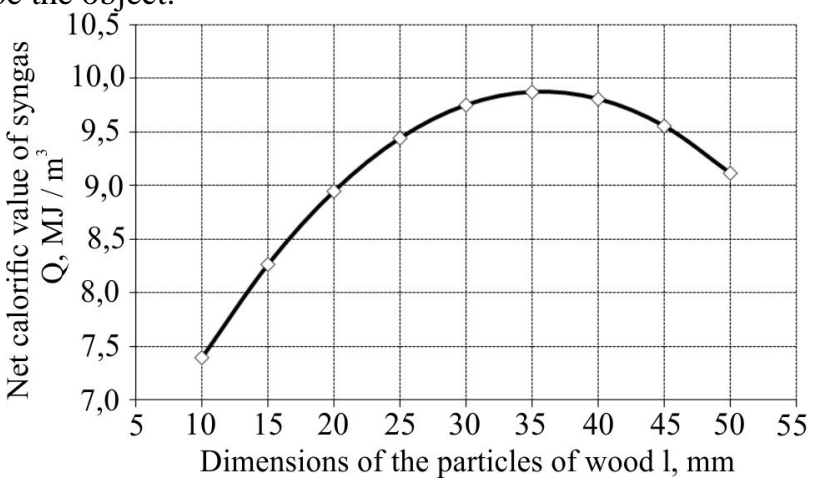

Fig. 2. Dependence of heat of syngas combustion on chopped wood size determined by regression equation with the given amount of air $\left(\mathrm{G}=70 \mathrm{~m}^{3} / \mathrm{hr}\right.$.) and the amount of wood in the gasifier reactor $(\mathrm{q}=$ $80 \%)$

Conclusions. The degree of wood chopping has been shown to significantly affect the gasification process. A significant increase in wood particle size $(l>50 \mathrm{~mm})$ leads to a decrease in the intensity of wood gasification process. During the gasification of wood chips of various degree of 
shredding, liquid products output changes (the smaller the wood particles the greater the output of total resins of absolutely dry wood weight). The obtained regression equation could be the basis for the process under study and rational process control. With equation of dependence of inputs on the original setting, we can predict every possible parameter for the estimation of the process under study at any values of the factors that are between the upper and lower levels.

\section{References}

Basu, Prabir. (2010). Biomass gasification and pyrolysis: practical design. Academic Press is an imprint of Elsevier, USA, 376 p.
Lyamyn, V. A., \& Nemkyn, A. S. (1940). Vlyyanye izmel'chenija drevesyny na vykhod zhydkykh produktov hazyfykatsyy. Lesokhymycheskaya promyshlennost, 8, 34-38. [in Russian].

Lys, S. S. (2017). The Analysis of Experimental Research of Gasification Process of Low-Grade Fuel. Scientific Bulletin of UNFU, 27(1), 154-156. https://doi.org/10.15421/40270136

Lys, S. S., \& Mysak, Yo. S. (2012). Termichna pererobka derevyny metodom sutsilnoho sharu v hazopodibne palyvo. Skhidno-Yevropeyskyy zhurnal peredovykh tekhnolohiy, 3/8(57), 47-49. [in Ukrainian].

Mysak, Yo., Lys, S., \& Martynyak-Andrushko, M. (2017). Research on gasification of low-grade fuels in a continuous layer. EasternEuropean Journal of Enterprise Technologies, 2(8), 16-23.

Pylypchuk, M. I., Hryhoryev, A. S., \& Shostak, V. V. (2007). Osnovy naukovykh doslidzhen. Lviv: Znannya, 234 p. [in Ukrainian].

С. С. Лис, Й. С. Мисак, Т. Ю. Кравець

Національний університет "Львівська політехніка", м. Львів, Украӥна

\section{ВПЛИВ ФРАКЦІЙНОГО СКЛАДУ ДЕРЕВИНИ НА ПРОЦЕС ГАЗИФІКАЦІЇ}

Сьогодні існує тенденція до децентралізації енергетики, тобто використання когенераційних установок для вироблення тепла та електрики. Перспективними когенераційними установками є двигуни внутрішнього згорання, які працюють на синтез-газі. Тому газифікація деревини для вироблення синтез-газу - найбільш перспективний і екологічний спосіб перероблення біомаси.

Теплотворна здатність синтез-газу, отримуваного внаслідок газифікації деревного палива, може змінюватися залежно від різних факторів. Основними факторами, які впливають на процес газифікації, є: фракційний склад деревини; кількість повітря, поданого в камеру газифікації; висота активного шару й інших факторів, залежних від палива, яке газифікується, i параметрів газифікатора. Будь-яку деревину для подальшого термічного перероблення потрібно подрібнити. У разі виробничої потреби, деревину подрібнюють до технологічної тріски різних фракцій рубальними машинами (їх ще називають деревними дробарками, шредерами). Вибір рубальної машини залежить від виробничої потреби. Сучасні рубальні машини дають змогу здійснювати тонке налаштування вихідного матеріалу за розміром деревини. Зважаючи на дефіцит і ціну енергоносіїв, на перший план виходить використання подрібнених деревних відходів як палива для газогенераторних установок та котлів на твердому паливі.

Ключові слова: теплотворна здатність синтез-газу; газогенераторна установка; процес газифікації деревини; фракційний склад деревини.

С. С. Лыс, И. С. Мысак, Т. Ю. Кравец

Наичинальный университет "Львовская политехника", г. Львов, Украина

\section{ВЛИЯНИЕ ФРАКЦИОННОГО СОСТАВА ДРЕВЕСИНЫ НА ПРОЦЕСС ГАЗИФИКАЦИИ}

Сегодня имеет место тенденция децентрализации энергетики, то есть использование когенерационных установок для выработки тепла и электричества. Перспективными когенерационными установками являются двигатели внутреннего сгорания, работающие на синтез-газе. Поэтому газификация древесины с целью выработки синтез-газа - наиболее перспективный и экологический способ переработки биомассы.

Теплотворная способность синтез-газа, получаемого в результате газификации древесного топлива, может изменяться в зависимости от различных факторов. Основными факторами, влияющими на процесс газификации, являются: фракционный состав древесины; количество воздуха, поданного в камеру газификации; высота активного слоя и ряда других факторов, зависящих от топлива, которое газифицируется, и параметров газификатора. Любую древесину для дальнейшей термической переработки нужно измельчить. В случае необходимости, древесину измельчают до технологической щепы различных фракций рубильными машинами (их еще называют древесными дробилками, шредерами). Выбор рубильных машин зависит от производственной необходимости. Современные рубильные машины позволяют производить тонкую настройку исходного материала по размеру древесины. Учитывая дефицит и цену энергоносителей, на первый план выходит использование измельченных древесных отходов в качестве топлива для газогенераторных установок и котлов на твердом топливе.

Ключевые слова: теплотворная способность синтез-газа; газогенераторная установка; процесс газификации древесины; фракционный состав древесины.

Інформація про авторів:

Лис Степан Степанович, канд. техн. наук, ст. викладач, Національний університет "Львівська політехніка", м. Львів, Україна. Email: lysss@ukr.net

Мисак Йосиф Степанович, д-р техн. наук, професор, Національний університет "Львівська політехніка", м. Львів, Україна. Email: Yosyp.S.Mysak@Ipnu.ua

Кравець Тарас Юрійович, канд. техн. наук, доцент, Національний університет "Львівська політехніка", м. Львів, Україна. Email: kravetst@ukr.net 